University of New Hampshire

University of New Hampshire Scholars' Repository

$1-1999$

\title{
Motivational characteristics associated with health and human service volunteers
}

Jerry D. Marx

University of New Hampshire, Jerry.Marx@unh.edu

Follow this and additional works at: https://scholars.unh.edu/socwork_facpub

Part of the Social Work Commons

\section{Recommended Citation}

Marx, J.D. (1999). Motivational characteristics associated with health and human service volunteers.

Administration In Social Work, 23(1), 51-66.

This Article is brought to you for free and open access by the Social Work at University of New Hampshire Scholars' Repository. It has been accepted for inclusion in Social Work Scholarship by an authorized administrator of University of New Hampshire Scholars' Repository. For more information, please contact

Scholarly.Communication@unh.edu. 
This article was downloaded by: [University of New Hampshire]

On: 24 August 2012, At: 11:48

Publisher: Routledge

Informa Ltd Registered in England and Wales Registered Number: 1072954

Registered office: Mortimer House, 37-41 Mortimer Street, London W1T 3J H, UK

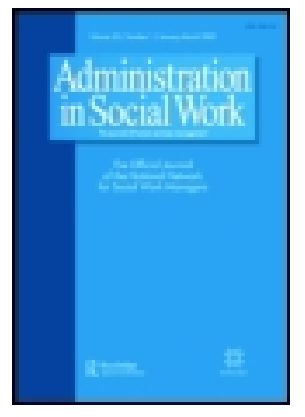

\title{
Administration in Social Work
}

Publication details, including instructions for authors and subscription information:

http:// www. tandfonline.com/loi/ wasw20

\section{Motivational Characteristics Associated with Health and Human Service Volunteers}

\author{
J erry D. Marx DSW ${ }^{\text {a }}$ \\ ${ }^{a}$ Department of Social Work, University of New \\ Hampshire, Durham, NH, 03824, USA \\ Version of record first published: 11 Oct 2008
}

To cite this article: J erry D. Marx DSW (1999): Motivational Characteristics Associated with Health and Human Service Volunteers, Administration in Social Work, 23:1, 51-66 To link to this article: http:// dx.doi.org/ 10.1300/ J147v23n01_03

\section{PLEASE SCROLL DOWN FOR ARTICLE}

Full terms and conditions of use: http://www.tandfonline.com/page/termsand-conditions

This article may be used for research, teaching, and private study purposes. Any substantial or systematic reproduction, redistribution, reselling, loan, sub-licensing, systematic supply, or distribution in any form to anyone is expressly forbidden.

The publisher does not give any warranty express or implied or make any representation that the contents will be complete or accurate or up to date. The accuracy of any instructions, formulae, and drug doses should be independently verified with primary sources. The publisher shall not be liable for any loss, actions, claims, proceedings, demand, or costs or damages 
whatsoever or howsoever caused arising directly or indirectly in connection with or arising out of the use of this material. 


\title{
Motivational Characteristics Associated with Health and Human Service Volunteers
}

\author{
Jerry D. Marx, DSW
}

Social work managers often utilize volunteers in the delivery of health and human services (Brudney, 1990; Ellis, 1986; McCurley \& Vineyard, 1986; Black \& DiNitto, 1994; Chambre, 1991; Osterkamp \& Chapin, 1995; Parsonnet \& Weinstein, 1957; Schondel, Shields, \& Orel, 1992; Weiler, 1995). During the 1960s, 70s, and 80s, the federal government took an active role in developing several national volunteer programs, including Volunteers in Service to America (VISTA), Foster Grandparents, the Retired Senior Volunteer Program, the Senior Companion Program, the National Executive Service Corps, and the National Retiree Volunteer Center (Chambre, 1993; Day, 1997). The Bush administration in the late 1980s and early 90s, and the Clinton administration, as we approach the year 2000, have continued to encourage volunteerism to enhance health and human services. A noteworthy example was the "President's Summit" on volunteerism held in Philadelphia in April of 1997 (McGrory, 1997).

The problem is that many health and human services have difficulty in attracting sufficient volunteers. Health $(8.8 \%)$ and human services $(8.4 \%)$ represented a far smaller percentage of the distribution of volunteer assignments in 1995 than religious (17.2\%) and educational $(11.6 \%)$ institutions (Hodgkinson \& Weitzman, 1996). People tend to volunteer for organizations in which members have the same characteristics as themselves (Chambre, 1991). As a result, it may be more difficult to attract volunteers in health and human services where the

Jerry D. Marx is Assistant Professor, Department of Social Work, University of New Hampshire, Durham, NH 03824.

Administration in Social Work, Vol. 23(1) 1999

(C) 1999 by The Haworth Press, Inc. All rights reserved. 
caseload, for example, is primarily intravenous drug users rather than a class of suburban elementary school children. Similarly, many potential volunteers are apprehensive about serving in high crime areas, the location of many health and human services. In addition, small grassroots health and human service organizations have more difficulty recruiting volunteers than larger, more prestigious institutions.

Added to all of this is the resistance of some professionals and organizations to the use of volunteers (Black \& DiNitto, 1994; Haeuser \& Schwartz, 1980). Some groups oppose the use of volunteers because unpaid work is thought to perpetuate the oppression of women. Volunteers are also perceived as a threat to job security by some professionally trained workers. And others may not have the resources to do adequate volunteer supervision.

\section{MOTIVATION AND VOLUNTEERISM}

Given the current national policy emphasis on volunteerism and the challenge facing health and human services in attracting volunteer support, there is a need for further research on volunteer service in the health and human services. What motivations are associated with volunteer activity? In addition, are there other demographic and socioeconomic factors that might be significantly related to volunteerism? These or similar questions have been the subject of a small number of recent studies (Black \& DiNitto, 1994; Bass \& Caro, 1995; Chambre, 1991, 1987, 1984; Gidron, 1985; Hodgkinson \& Weitzman, 1996; Morrow-Howell \& Mui, 1959; Nathanson \& Eggleton, 1993; Stevens, 1991; Stulberg \& Smith, 1988; Walsh, 1986; Zakour, 1994).

While there is empirical evidence (Bass \& Caro, 1995; Black \& DiNitto, 1994; Nathanson \& Eggleton, 1993; Morrow-Howell \& Mui, 1989) that "altruism" (i.e., a selfless regard for the well-being of others) is a significant volunteer motivation, studies have also found several other motivations for volunteering. For example, some volunteers like to feel needed. Bass and Caro (1995), examining the findings of the 1991 Commonwealth Fund Productive Aging Survey, state that knowing their "help is appreciated" (with no special thanks) was significantly more attractive than other forms of recognition for older volunteers (p. 90). The authors also found gender, age, education, health, and religious activity to be significant predictors of elderly 
volunteering in the health sector, while religious activity had a significant negative association with elder volunteering in social service (i.e., human service) institutions (p. 81).

Morrow-Howell and Mui (1989) interviewed 83 adults participating in a self-help program in St. Louis. Participants were primarily older (average age 65), African American (74\%), and women (90\%). Female volunteers indicated (p. 28) that they volunteered for psychosocial reasons ("to feel needed" and "to talk to people" were the responses most frequently given).

Two studies (Chambre, 1991; Stulberg \& Smith, 1988) found volunteering to be an effective coping strategy. Chambre (1991), in a qualitative study on volunteerism, interviewed $30 \mathrm{key}$ informants involved in the AIDS crisis in New York City during the 1980s. A primary finding of this study (p. 531) was that individuals volunteered to support patients with AIDS as a way of coping with the uncertainties of the disease in their own lives. Stulberg and Smith (1988) surveyed 301 gay men in the Los Angeles area to examine the impact of the AIDS epidemic on gay lifestyles. One finding of the study (pp. 277-281), consistent with the Chambre study (1991), was that volunteering for AIDS organizations was one of the most helpful ways of coping with AIDS-related stress.

The work of one researcher (Gidron, 1985) shows the opportunities inherent in volunteer assignments for gaining new perspectives on life. The author identified predictors of retention and turnover among volunteers in three Israeli community centers. "The work itself" (i.e., challenging, interesting, etc.) was found to be one of the best discriminators between those who stayed volunteers and those who left by choice.

Past research (Zakour, 1994; Stevens, 1991) has also shown volunteering to offer rewards like career advancement and peer recognition. A study by Zakour (1994) emphasized the fact that volunteerism is often motivated by a desire for personal career development. As part of a larger study of American Red Cross volunteers, 541 (40\%) respondents indicated that the reason for initially volunteering was "to obtain training and skills." Research on 151 senior volunteers, ages 60 to 93, by Stevens (1991), showed that one reward associated with volunteer satisfaction and retention was perceived recognition for their efforts.

Other studies (Chambre, 1957; Walsh, 1986) have found several 
demographic characteristics, in addition to those already identified, to be significantly associated with volunteering. Chambre (1987) did a secondary analysis of data obtained in a 1981 survey by the National Council on Aging. The author found that the factors with the strongest influence on volunteer activity among people aged 60 and over $(\mathrm{n}=$ 2,088 ) were a person's overall activity level, educational achievement, life satisfaction, and age.

Like Chambre, Walsh (1986) used data from the 1981 survey by the National Council on Aging to analyze volunteerism. This study, in contrast to the Chambre research, focused only on those respondents aged 65 and over $(n=1,837)$. The results showed health and income to be significantly related to volunteer activity.

The present study uses this prior research to identify possible motivational factors associated with volunteering. The previously cited studies, however, have been limited by small samples (Black \& DiNitto, 1995; Chambre, 1991; Gidron, 1985; Morrow-Howell \& Mui, 1989; Stevens, 1991), have analyzed only one group of people, like older volunteers, for example (Bass \& Caro, 1995; Chambre, 1987, 1984; Nathanson \& Eggleton, 1993; Stulberg \& Smith, 1988; Walsh, 1986), and/or have not focused on factors effecting volunteerism specifically in the health and human services (Chambre, 1987, 1984; Hodgkinson \& Weitzman, 1996; Walsh, 1986). The primary publication using the data set employed in this study (Hodgkinson \& Weitzman, 1996) provides a general overview of charitable giving and volunteering in the United States.

The aim of this study, a secondary analysis of national survey data collected for the Independent Sector by The Gallup Organization, was to examine various motivational factors associated with volunteering specifically in the health and human services. Significant findings may be helpful to administrators in the health and human services as they compete with other fields for available volunteers.

More precisely, the study addresses the following two research questions:

1. Are there motivational characteristics that distinguish people likely to volunteer in health services from other groups of people?

2. Are there motivational characteristics that distinguish people likely to volunteer in human services from other people? 


\section{METHODS}

\section{Sample}

The information for the study was taken from a representative national sample of 2,719 adult Americans, 18 years of age and over. To ensure a sufficient number of blacks, Hispanics, and affluent Americans for statistical analysis, a multistage cluster sampling procedure with stratification was used. "Affluent" was defined as those households with incomes over $\$ 60,000$. Sampling did not include people residing on military bases, the institutionalized and the homeless. The final sample was representative of the U.S. adult population in terms of education, age, marital status, occupation, size of household, region of the country, and household income (Hodgkinson \& Weitzman, 1996, p. xiv).

\section{Data Collection Procedure}

A questionnaire was administered during in-home face-to-face interviews conducted from May 4 to June 16th of 1996 by The Gallup Organization. Interviews were conducted in English, and when necessary, Spanish. The questionnaire covered both charitable giving and volunteering. The instrument consisted of a total of 82 questions, including a variety of structures (open and closed-ended items, contingency questions) and formats (matrix questions, various rating scales). Except for income, data on volunteerism were collected for the individual interviewed only. Individuals know how much time they volunteer, but do not tend to reliably report on the volunteer efforts of other household members. In contrast, since income is often related to the entire family, data were collected on aggregate household income (Hodgkinson \& Weitzman, 1996, p. xiv).

\section{Data Analysis Strategy}

This study, as previously stated, represents a secondary analysis of a national data set. The Independent Sector, through national surveys conducted for it by The Gallup Organization, is the primary source of data on American volunteerism. Much of the prior research on volunteerism by independent researchers is limited by small samples (Black 
\& DiNitto, 1995; Chambre, 1991; Gidron, 1985; Morrow-Howell \& Mui, 1989; Stevens, 1991). This is due in part to the enormous time and costs involved in national surveys. By conducting a secondary analysis of the Independent Sector's national data set, the present study was able to cull a subset of health and human service volunteers large enough to examine with multivariate statistical procedures.

Based upon the preceding literature review, it is likely that various motivations for volunteering may be correlated with each other and with certain demographic characteristics. Therefore, logistic regression, a multivariate statistical technique, was used to examine the relationship of each motivation to health or human service volunteerism, while controlling for the effects of other motivational and demographic characteristics. Logistic regression is preferred to multiple regression analysis or discriminant analysis when the dependent variable can have only two values, an event occurring or not occurring, as in this study (Norusis, 1990, p. 45).

\section{Measurement of Health and Human Service Volunteerism}

"Volunteering" is defined in this study as "actual work in formal service organizations to help others for no monetary pay." The questionnaire measured "health" and "human service" as two distinct categories, among a list of 15 different possible volunteer areas. Interviewers were asked to refer to a list of more specific services for each of the 15 volunteer categories, including both health and human services. (Presumably, this was for the purpose of further defining each category for the respondent, although it is not possible to determine for certain.)

Health services were defined in this survey as follows: general and rehabilitation, including organizations for mental health, mental retardation and developmentally disabled; substance abuse agencies; research and public education concerning diseases; hospitals, nursing homes, hospices, clinics, crisis counseling, hotlines; fund drives of private health associations such as the American Cancer Society and American Heart Association.

In addition, human services were categorized as: foster care; family counseling; child care centers; legal aid; consumer protection; crime and delinquency prevention; homeless services; employment/job support; food; housing/shelter; emergency preparedness and relief; recreation; Red Cross, YMCA, United Way, Catholic Charities, Protestant 
Welfare Agencies, United Jewish Appeal, and other federated campaigns (Hodgkinson \& Weitzman, 1996, p. C138).

Survey participants were asked to respond "yes" or "no" to whether or not they had volunteered in the past twelve months in "health organizations." Respondents were later asked to respond "yes" or "no" to whether or not they had volunteered in the past twelve months in "human services." To measure "health volunteer status" and "human service volunteer status" in this study, responses were coded 1 for yes and 0 for no.

\section{FINDINGS}

\section{Description of Survey Participants}

Of the 2,719 survey participants, $51.5 \%(\mathrm{n}=1,400)$ were female; $48.5 \%(\mathrm{n}=1,319)$ were male. About three-quarters of the sample $(73.7 \%, \mathrm{n}=2,004)$ listed themselves as white, while about one-quarter of the sample $(24.8 \%, \mathrm{n}=674)$ identified as a minority. The average age of participants was 46.5 years. Over a third of the sample (34.0\%, $\mathrm{n}=925)$ listed a high school diploma as their highest degree, while $26.4 \%(n=718)$ held a two- or four-year college degree. The median income fell in the $\$ 30,000$ to $\$ 34,999$ category. Close to half of respondents $(46.4 \%, \mathrm{n}=1,262)$ were employed full-time; $11.2 \%(\mathrm{n}=$ 304 ) worked part-time. About sixty-five percent $(64.5 \%, n=1,755)$ of survey participants were either married or living with a partner. Over $12 \%(12.2 \%, \mathrm{n}=331)$ of respondents had done some volunteer work (i.e., at least one volunteer assignment) in health services during the 12 months prior to participating in the survey, while close to $11 \%$ $(10.7 \%, \mathrm{n}=290)$ of the sample had completed some volunteer work in human service organizations during the prior 12 months.

\section{Motivations for Volunteering in General}

The previous review of empirical studies identified several motivational characteristics associated with volunteering that can be measured using the Independent Sector data set: peer recognition, altruism, career development, to gain a new perspective, to feel needed, and to cope with personal problems. 
The questionnaire included one question that asked: "If you have done volunteer work before or are currently volunteering, I would like to ask your reasons for volunteering. If you have not volunteered before, I'd like to know what reasons for volunteering would be important to you." Respondents were then asked to rate the importance of several reasons for volunteering. For this study, all responses in this sequence of items were coded from 4 for Very important to 1 for Not at all important.

In this sample of 2,719 Americans (see Table 1), "altruism" was rated as "somewhat important" or "very important" by $81.5 \%(\mathrm{n}=$ 2216) of respondents. By definition, altruism involves a selfless regard for the well-being of others (Woolf, 1975). The questionnaire item, "I feel compassion toward people in need," was used to measure the variable "altruism" in this study.

"To feel needed," "to gain a new perspective," and "peer recognition" were also rated by a majority of respondents as either somewhat important or very important motivations for volunteering. Close to $63 \%$ of survey participants $(62.5 \%, \mathrm{n}=1,700)$ rated the questionnaire item "Volunteering makes me feel needed" as an important motivation; about $61 \%(61.1 \%, \mathrm{n}=1,660)$ of participants rated the questionnaire item "Volunteering allows me to gain a new perspective on things" as important.

Another possible response was "Volunteering is an important activity to the people I respect." This questionnaire item was used to measure the variable "peer recognition." A little over half of respondents $(56.5 \%, \mathrm{n}=1,535)$ considered this motivation as important.

TABLE 1. Motivations for Volunteering in General $(N=2719)$

\begin{tabular}{lrccc} 
Motivation & $\begin{array}{c}\text { Not At All } \\
\text { Important } \\
\mathrm{n}(\%)\end{array}$ & $\begin{array}{c}\text { Not Too } \\
\text { Important } \\
\mathrm{n}(\%)\end{array}$ & $\begin{array}{c}\text { Somewhat } \\
\text { Important } \\
\mathrm{n}(\%)\end{array}$ & $\begin{array}{c}\text { Very } \\
\text { Important } \\
\mathrm{n}(\%)\end{array}$ \\
\hline Peer recognition & $460(16.9)$ & $548(20.2)$ & $881(32.4)$ & $654(24.1)$ \\
Altruism & $141(5.2)$ & $223(8.2)$ & $973(35.8)$ & $1243(45.7)$ \\
Career develop. & $1315(48.4)$ & $573(21.1)$ & $403(14.8)$ & $236(8.7)$ \\
New perspective & $411(15.1)$ & $463(17.0)$ & $945(34.8)$ & $715(26.3)$ \\
Feel needed & $381(14.0)$ & $471(17.3)$ & $944(34.7)$ & $756(27.8)$ \\
Coping & $908(33.4)$ & $589(21.7)$ & $613(22.5)$ & $404(14.9)$ \\
\hline
\end{tabular}


A much smaller percentage of survey participants $(37.4 \%, \mathrm{n}=$ 1,017 ) believed volunteering to be an important coping strategy. "Volunteering helps me to deal with some of my own personal problems" (i.e., a coping strategy) was the questionnaire item used to measure this variable.

The question also included the following motivation for volunteering: "I can make new contacts that might help my business or career." This item was used in this study to measure the variable "career development." However, only $23.5 \%(\mathrm{n}=639)$ of the sample regarded this motivation as important.

\section{Motivations for Health Volunteers}

When the relationship of each independent variable to "health volunteer status" was examined while controlling for the effects of the remaining independent variables (see Table 2), significant differences in motivation between those that volunteered in health services and those that did not were found only in one area. The coefficient (B) in Table 2 indicates that those volunteering in health organizations were more likely to identify the motivation "to gain a new perspective" as

TABLE 2. Logistic Regression Predicting Health Volunteer Status ( $N=878$ )

\begin{tabular}{lccr} 
Variable & $\begin{array}{c}\text { Estimated } \\
\text { Coefficient }(\mathrm{B})\end{array}$ & SE & Exp (B) \\
\hline Peer recognition & .0844 & .0889 & 1.0881 \\
Altruism & .2211 & .1307 & 1.2350 \\
Career development & -.0578 & .0832 & .9438 \\
Gain new perspective & $.2197^{\star}$ & .1046 & 1.2457 \\
Feel needed & -.1053 & .0941 & .9000 \\
Coping strategy & .0850 & .0822 & 1.0888 \\
Gender & $.2821^{\star \star \star}$ & .0796 & 1.3259 \\
Overall activity level & $-.1016^{\star \star \star}$ & .0220 & .9034 \\
Educational level & $.1111^{\star \star \star}$ & .0314 & 1.1175 \\
Total annual income & .0042 & .0188 & 1.0042 \\
Religious activity & $-.1872^{\star \star}$ & .0706 & .8293 \\
Age & $.0311^{\star \star \star \star}$ & .0053 & 1.0316 \\
\hline
\end{tabular}

${ }^{\star} \mathrm{p}<.05,{ }^{\star \star} \mathrm{p}<.01,{ }^{\star \star \star} \mathrm{p}<.001,{ }^{\star \star \star \star} \mathrm{p}<.0001$ 
an important reason for volunteering. The figure in column $\operatorname{Exp}(B)$ indicates that those listing "to gain a new perspective" as an important reason for volunteering were about $25 \%$ more likely $[\operatorname{Exp}(B)=$ 1.2457] to volunteer in health organizations than those respondents who did not see this as an important reason.

Several other independent variables were also found significantly related to health volunteering. In terms of demographic characteristics, those who volunteer in health organizations, in contrast to those who do not, were more likely to be female, older, and higher educated. In addition, given the Bass and Caro (1995) findings, a measure for "religious activity" was included in this study. The variable was measured with a questionnaire item that asked respondents to rate the frequency of their church or synagogue service attendance. Health service volunteers in this sample tended to be less active in religious activities.

And last, "overall activity level" was defined in this study as the level of participation in social activities in general. The variable was computed using a question that asked respondents to indicate how often they spent time socially with people from various areas in their life: relatives, neighbors, other friends, work or professional organizations, church or synagogue, voluntary or service organizations, and sports or recreation. In this study, health volunteers, when compared to others in the sample, tended to be less active overall in these areas of their social life.

\section{Motivations for Human Service Volunteers}

The logistical regression analysis for human service volunteering (Table 3) produced slightly different results than the analysis for health volunteers. Those who volunteer in human services, in comparison to those who do not, were more likely to state "altruism" and "to gain a new perspective" as reasons for volunteering. The figure in column $\operatorname{Exp}(B)$ indicates that those listing altruism as an important motivation for volunteering were about $32 \%$ more likely $[\operatorname{Exp}(\mathrm{B})=$ $1.3240]$ to volunteer in human services than respondents who did not see this as an important motivation. In addition, respondents that consider gaining new perspectives on life an important reason for volunteering were about $25 \%$ more likely $[\operatorname{Exp}(B)=1.2534]$ to volunteer in human services than those respondents who did not see this as an important reason. 
TABLE 3. Logistic Regression Predicting Human Service Volunteer Status $(\mathrm{N}=869)$

\begin{tabular}{lccr} 
Variable & $\begin{array}{c}\text { Estimated } \\
\text { Coefficient (B) }\end{array}$ & SE & Exp (B) \\
\hline Peer recognition & -.0373 & .0881 & .9634 \\
Altruism & $.2807^{\star}$ & .1293 & 1.3240 \\
Career development & .0393 & .0804 & 1.0401 \\
New perspective & $.2259^{\star}$ & .1037 & 1.2534 \\
Feel needed & -.1242 & .0923 & .8832 \\
Coping strategy & .0373 & .0816 & 1.0380 \\
Gender & -.1151 & .0777 & .8913 \\
Overall activity level & $-.0631^{\star *}$ & .0216 & .9389 \\
Educational level & $.0748^{\star}$ & .0310 & 1.0777 \\
Total annual income & .0088 & .0188 & 1.0088 \\
Religious activity & -.1314 & .0693 & .8768 \\
Age & .0030 & .0052 & 1.0030 \\
\hline
\end{tabular}

${ }^{\star} \mathrm{p}<.05,{ }^{\star \star} \mathrm{p}<.01$

Furthermore, human service volunteers tended to be more highly educated and less active overall in their social life. It should be noted that the variable "religious activity" approached significance $(p=.06)$ in the logistic equation. Respondents who volunteer in human services, in contrast to those who don't, appeared less involved in religious activity.

\section{LIMITATIONS OF THE STUDY}

This study, as stated earlier, is a secondary analysis of national survey data. Reliability is generally strong in survey research, particularly when standardized questionnaires are used, as in this survey (Rubin \& Babbie, 1993). However, standardized questionnaires tend to be somewhat superficial, thus limiting validity. Furthermore, this study, like all secondary analysis, is limited by the fact that variable operationalization is confined to the existing measurement instrument and data. As a result, validity is generally not as high as when data are collected directly by the researcher for a specific purpose (Rubin \& Babbie, 1993). 
For example, the questionnaire used in this study contained only one questionnaire item for each possible volunteer motivation. Future research needs to provide multiple measurements of volunteer motivations. In so doing, volunteer motivations like "altruism" and "gaining new perspectives" could be more fully examined. The variable "to gain a new perspective" could be further operationalized into more specific items like "to gain new perspectives on gay and lesbian lifestyles," "to gain new perspectives on diverse racial and ethnic cultures," and "to gain new perspectives on death and dying." With respect to "altruism," are respondents who claimed altruism as an important reason for volunteering as likely to volunteer with older Americans as younger Americans or with black Americans as white Americans? These issues need to be explored in more depth.

Additionally, more descriptive information about the health and human service settings of volunteers needs to be obtained, so that possible relationships between specific agency settings and individual motivations can be examined. Are volunteers who are motivated by altruism more attracted to advocacy organizations than more direct service organizations? The existing questionnaire provides limited information in this regard.

Similarly, the existing instrument does not address the "quality" of volunteer work. Future studies, possibly including field research, might explore potential associations between volunteer motivational characteristics and the quality of volunteer work. Is the work quality of volunteers who are motivated by career development concerns generally better than the quality of those motivated by a desire to gain new perspectives on things or by altruism? Given the limited time that many agencies have for volunteer supervision, the quality of volunteer efforts is important.

\section{IMPLICATIONS}

Health and human services might do well, when competing with other fields such as education and religion in the recruitment of volunteers, to reemphasize the intrinsic benefits of volunteering in their organizations. This study suggests that altruism and gaining new perspectives on life are significant motivations for people who volunteer in the human services. Likewise, gaining new perspectives is a significant motivator for volunteers in health services as well. 
Based upon these findings, health and human service managers involved in volunteer recruitment and supervision are advised to:

- Keep volunteers informed about the positive outcomes of agency services. Those who volunteer for altruistic reasons, for example, are motivated by knowing that their efforts made a difference to others. They need to know the broader significance of what they are doing. They need to know how their specific tasks contribute to the overall mission of the agency and to the society at large. For instance, given the increasing demand by funding sources for outcome measures in social services, the results of these program evaluations could be shared with volunteers in an agency annual report or newsletter. In addition, health and human service managers often ask program clients to attend allocation sessions to provide testimony to potential funders regarding program benefits. Program clients can perform a similar function at volunteer recruitment or training sessions.

- Emphasize what volunteers learn at your agency. People who volunteer to gain new perspectives on life need to hear, during recruitment and training, what opportunities for personal growth and development are offered in agency programs. To illustrate, hospice agencies often educate new volunteer recruits about the various cultural beliefs concerning death in our society. Such training offers volunteers an opportunity for spiritual growth and development. Foster grandparent programs educate new volunteers about priority community needs, particularly in relation to volunteer assignments. This training provides a way for older Americans to become connected to and involved in their communities, a common desire of older Americans. What is more, former and long-time volunteers can be used in recruitment and training sessions to share their experiences with new and potential volunteers.

- Invite program donors to volunteer. Individual donors to private nonprofit health and human services may desire more direct involvement than sending a check once a year. These may be people doing very well in the corporate world and, in altruistic fashion, want to give something more to the community. Nothing is expected in return. Volunteerism allows them to stay in the corporate world while satisfying their altruistic needs. 
- Place less emphasis in volunteer recruitment and retention on the motivational rewards not found significant in this study. Health and human service volunteers in this study, for example, were not motivated by career development concerns. Therefore, appeals that stress volunteering as a way to make professional contacts, to gain work experience, or eventually secure an entry level position in a particular agency, may be less effective in social work.

- Similarly, those who volunteered in health or human services in this study were not particularly concerned about peer recognition. This finding makes sense, given the fact that most private nonprofit organizations are small, grassroots agencies doing very unglamorous work. Hence, social administrators involved in volunteer recruitment may want to place less emphasis on appeals to the "prestige" and "status" associated with volunteering, strategies that may be better suited for large educational institutions and arts/cultural organizations. For the same reason, expensive recognition awards and banquets may be less appealing to health and human service volunteers who would rather focus limited resources on "the cause" (i.e., assisting those in need).

\section{CONCLUSION}

The goal of American social administration should be the most effective integration of professionalism and volunteerism in delivering public and private sector services. This integration would use volunteers to enhance the work, not substitute for the work, of professionals. Volunteers can enhance professional services in many ways. Volunteers can serve as intermediaries between professionals and clients of diverse backgrounds. Volunteers can extend the work of professionals in organizations with limited staff. Volunteers can help to humanize the work of professionals in typically impersonal bureaucracies. And volunteers, partly because they are unpaid, can serve as effective legislative advocates and community fund raisers.

For these reasons, social work managers need to become more effective in recruiting volunteers. Those administrators who recruit and/or supervise volunteers must consider the unique motivations of health and human service volunteers. This study suggests that altruism and gaining new perspectives on life are significant motivations for 
people who volunteer in the human services. Gaining new perspectives is also a significant motivator for health volunteers. Potential motivators like career development, feeling needed, peer recognition, and coping with personal problems do not appear to be significant to health and human service volunteers. Administrators, therefore, should consider developing volunteer management strategies that reflect these distinctions.

\section{REFERENCES}

Bass, S.A., \& Caro, F.G. (1995). Increasing volunteering among older people. In S. Bass (Ed.), Older and active: How Americans over 55 are contributing to society. New Haven: Yale University Press.

Black, B., \& DiNitto, D. (1994). Volunteers who work with survivors of rape and battering: Motivations, acceptance, satisfaction, length of service, and gender differences. Journal of Social Service Research, 20(1/2), 73-97.

Brudney, J.L. (1990). Fostering volunteer programs in the public sector. San Francisco: Jossey-Bass.

Chambre, S.M. (1993). Volunteerism by elders: Past trends and future prospects. The Gerontologists, 33(2), 221-228.

Chambre, S.M. (1991, December). Volunteers as witnesses: The mobilization of AIDS volunteers in New York City, 1981-1988. Social Service Review, 531-547.

Chambre, S.M. (1987). Good deeds in old age: Volunteering by the new leisure class. Lexington, MA: Heath.

Chambre, S.M. (1984). Is volunteering a substitute for role loss in old age? An empirical test of activity theory. The Gerontologist, 24(3), 292-298.

Day, P.J. (1997). A new history of social welfare. Boston: Allyn \& Bacon.

Ellis, S.J. (1986). From the top down: The executive role in volunteer program success. Philadelphia: Energize Associates.

Gidron, B. (1985). Predictors of retention and turnover among service volunteer workers. Journal of Social Service Research, 8(1), 1-16.

Haeuser, A.A., \& Schwartz, F.S. (1980, December). Developing social work skills for work with volunteers. Social Casework: The Journal of Contemporary Social Work, 595-600.

Hodgkinson, V.A., \& Weitzman, M.S. (1996). Giving and volunteering in the United States: Findings from a national survey. 1996 edition. Washington, DC: Independent Sector.

McCurley, S., \& Vineyard, S. (1986). 101 ideas for volunteer programs. Downers Grove, IL: Heritage Arts Publishing.

McGrory, B. (1997, October 20). Few answer the call of volunteer summit. The Boston Globe, p. C14.

Morrow-Howell, N., \& Mui, A. (1989). Elderly volunteers: Reasons for initiating and terminating service. Journal of Gerontological Social Work, 13(3/4), 21-34.

Nathanson, I.L., \& Eggleton, E. (1993). Motivation versus program effect on length 
of service: A study of four cohorts of ombudservice volunteers. Journal of Gerontological Social Work, 19(3/4), 95-114.

Norusis, M.J. (1990). SPSS advanced statistics user's guide. Chicago: SPSS, Inc.

Osterkamp, L.B., \& Chapin, R.K. (1995). Community-based volunteer home-repair and home-maintenance programs for elders: An effective service paradigm. Journal of Gerontological Social Work, 24(1/2), 55-75.

Parsonnet, L., \& Weinstein, L. (1987, Winter). A volunteer program for helping families in a critical care unit. Health And Social Work, 21-27.

Rubin, A., \& Babbie, E. (1993). Research methods for social work. Pacific Grove, CA: Brooks/Cole.

Schondel, C., Shields, G., \& Orel, N. (1992). Development of an instrument to measure volunteer's motivation in working with people with AIDS." Social Work in Health Care, 17(2), 53-71.

Stevens, E.S. (1991). Toward satisfaction and retention of senior volunteers. Journal of Gerontological Social Work, 16(3/4), 33-41.

Stulberg, I., \& Smith, M. (1988). Psychological impact of the AIDS epidemic on the lives of gay men. Social Work, 33(3), 277-281.

Walsh, E.M. (1986, May).Volunteerism among the elderly: A secondary analysis of a national survey [CD ROM]. Abstract from: Social Work Abstracts: Dissertation Abstracts Item: 1211.

Weiler, J.B. (1995). Respite care for HIV-affected families. Social Work in Health Care, 21(1), 55-67.

Woolf, H.B. (Ed.) (1975). Webster's new collegiate dictionary. Springfield, MA: Merriam.

Zakour, M.J. (1994). Measuring career-development volunteerism: Guttman scale analysis using Red Cross volunteers. Journal of Social Service Research, 19(3/4), 103-120. 